\title{
Spatial Patterns and Dynamics of some Halophytic Plants in the Hortobágy Region (Eastern Hungary)
}

\author{
Tibor Novák \\ Department for Landscape Protection and Environmental Geography, \\ University of Debrecen, H-4010, Debrecen, Egyetem tér 1. pf. 9 \\ e-mail: novak.tibor@science.unideb.hu
}

\begin{abstract}
Summary. Frequencies of 44 halophytic plants within 10 study sites in the Hortobágy were established, and the species were sorted by degree of salt tolerance. Number and frequency of $\beta$-mezohalin, $\alpha$-mezohalin and oligohalin species was found higher than species number and frequencies of eu-, polihalin and hipersalin species. This shows, that the extremely salt-stress as environmental factor is rare on the Hortobágy.
\end{abstract}

Key words: Hortobágy, halophytes, frequency, spatial pattern.

\section{Introduction}

On the Hortobágy area the first National Park of Hungary was settled in 1973. Since that is the question of origin and spatial pattern of alkaline and saline habitats more actually, to base the most successful maintenance methods of them. This study aimed to differ halophytic plants of different salt tolerance degree by their frequencies within 10 study sites.

\section{Study area}

In frame of some vegetation and landscape history reports the southern Hortobágy area was investigated. This landscape is dominated by grasslands situated in Eastern Hungary. As a result of geological, physio-geographical and climatic conditions - such as poor drainage, relatively low morphological situation, shallow groundwater level, and its alkaline character, high carbonate content of parent material, which causes the alkalinity and the hydrolysis of soil minerals (Szabolcs 1981) - 74\% of the Hortobágy is covered by salt affected soils (Marosi \& Somogyi 1990). The most present soil taxa of the Hortobágy are solonetz soils. On the basis of the thickness of leached „A" horizon, sodium adsorption rate (ESP), content of water soluble salts (mostly: $\mathrm{Na}_{2} \mathrm{CO}_{3}, \mathrm{NaHCO}_{3}, \mathrm{Na}_{2} \mathrm{SO}_{4}$, but also $\mathrm{NaCl}$ ) numerous subtypes can be distinguished. Deeper surface forms are covered with meadow soils, which subsoil is often influenced by alkalinization processes. Since the agricultural land use of alkaline soils is very limited, the anthropogenic disturbances and the transformation of soils occurred relatively late. Most of alkaline soils were never ploughed or disturbed in other ways, but changes in soil chemistry caused by water regulations, drainage or chemical reclamation are typical processes of the last decades.

The land use was traditionally cattle grazing, which is declining in the last decades. Soil transformations caused by water regulations, drainage or chemical reclamation are typical processes of the last century. The study area contains also conservation areas (National Park Hortobágy) with sheep grazing, but also non-protected, ameliorated meadows and abandoned fields dominated by secondary succession processes. 
Table 1. Distribution of salt tolerant plant species by salt tolerant categories found on the study sites, frequencies and names of most frequents for each category

\begin{tabular}{|l|c|c|l|}
\hline $\begin{array}{c}\text { Salt-tolerance (Ellenberg et } \\
\text { al. 1992; Borhidi 1993) }\end{array}$ & $\begin{array}{c}\text { Number of salt tolerant species } \\
(\mathbf{S B}>\mathbf{1}) \text { found on the study sites }\end{array}$ & Frequency & $\begin{array}{l}\text { Plant species with highest frequency of } \\
\text { his salt tolerance category }\end{array}$ \\
\hline oligohalin & 7 & IV & Polygonum aviculare \\
\hline$\beta$-mezohalin & 9 & V & Festuca pseudovina \\
\hline$\alpha$ - $\beta$-mezohalin & 6 & III & Eleocharis uniglumis \\
\hline$\alpha$-mezohalin & 7 & IV & $\begin{array}{l}\text { Artemisia santonicum ssp. monogyna } \\
\text { Podospermum canum }\end{array}$ \\
\hline$\alpha$-mezohalin/polihalin & 4 & II & $\begin{array}{l}\text { Beckmannia eruciformis } \\
\text { Hordeum hystrix }\end{array}$ \\
\hline polihalin & 4 & II & $\begin{array}{l}\text { Limonium gmelinii } \\
\text { Atriplex litoralis }\end{array}$ \\
\hline euhalin & 4 & III & Puccinellia limosa \\
\hline hipersalin & 3 & I & Camphorosma annua \\
\hline
\end{tabular}

\section{Research methods}

The field observations were carried out between 19982008. 10 different locations were investigated. On each location absence or presence of halophytic plant species were registered. From the data collected in field frequencies of halophytic plants were calculated. Salt tolerance degrees of the species were taken into consideration by Ellenberg, and Borhidi salt indication values. Halophytic species with SB value $>1$ : oligo-, mezo-, poli-, euhalin and hipersalin species by Borhidi (1993) and Ellenberg et al. (1992) were involved in the calculation. In case of some hipersalin, eu- and polihalin species (Suaeda salinaria, Lepidium crassifolium, Plantago maritima and Plantago schwarzenbergiana) a detailed field mapping was carried out.

\section{Results and discussion}

The highest number of species was found in oligohalin and $\beta$-mezohalin categories. Euhalin and hipersalin species were found in lower number. Also frequencies of polihalin, euhalin and hipersalin species are lower than frequencies of slightly salt tolerant species. Therefore the most frequent salt tolerant species were $\beta$-mezohalin, $\alpha$-mezohalin and oligohalin species (Tab. 1). Lower frequency of strongly salt tolerant plants underlies that really halophytic habitats are in the Hortobágy rather rare, especially on sites, were alkalization becams more present only after the river regulations in 19 century (Molnár \& Borhidi 2003).

The frequency data of the different salt tolerant species shows that the really strong salt-stress as environmental factor is not the most on the randomly chosen study sites. Some of euhalin or hipersalin species mentioned in the Flora of Hortobágy (Szujkó-Lacza 1982) i (Suaeda salinaria, Salicornia prostrata) were absent in the 10 sites, therefore in one site we found Lepidium crassifolium (euhalin), which was formerly not mentioned from the Hortobágy (Novák \& Matus 2000).

\section{References}

Borhidi A., 1993, A magyar flóra szociális magatartás típusai természetességi és relatív ökológiai értékszámai [Social behaviour types of the Hungarian flora, its naturalness and relative ecological indicator values in Hungarian], JPTE, Növénytani Tanszék, Pécs.

Ellenberg H., Weber H. E., Düll R., Wirth V., Werner W. \& Paulissen D., 1992, Zeigerwerte von Pflanzen in Mitteleuropa, Scripta Geobotanica 18: 44.

Marosi S. \& Somogyi S., (eds.), 1990, Magyarország kistájainak katasztere [Cadastre of Hungarian landscapes in Hungarian], MTA Földrajztudományi Kutató Intézet, Budapest.

Molnár Zs. \& Borhidi A., 2003, Hungarian alkali vegetation, Origins, landscape history syntaxonomy, conservation, Phytocoenologia 33 (2-3): 377-408.

Novák T. \& Matus G., 2000, Lepidium crassifolium W. et K. a Hortobágyon, Kitaibelia 5 (1): 189-194.

Szabolcs I., 1981, Salt affected Soils in the Hungarian Danube and Tisza Valleys, Agrokémia és talajtan 30 (suppl.): 213-218.

Szujkó-Lacza J., (ed.), 1982, The Flora of the Hortobágy National Park, Akadémiai Kiadó, Budapest. 